\title{
KONSEP DIRI: ANALISIS KESADARAN LINGKUNGAN KAUM VEGAN DAN VEGETARIAN DI BRITANIA RAYA
}

\author{
Lila Nathania ${ }^{1 *}$, Bobie Hartanto ${ }^{2}$ \\ ${ }^{1,2}$ Communication Science Department, Faculty of Economics and Communication, Bina Nusantara University, \\ Jakarta, Indonesia 11480 \\ Email: 1*lila.nathania@binus.edu; ${ }^{2}$ bhartanto@binus.edu \\ *Penulis korespondensi
}

\begin{abstract}
ABSTRAK
Konsep diri merupakan kesadaran tiap individu yang kompleks dan melibatkan proses pemikiran mendalam. Dalam proses pembentukan konsep diri, seorang individu dipengaruhi oleh berbagai faktor internal maupun eksternal. Konsep diri kita dalam menjaga atau merusak lingkungan ternyata dibentuk melalui kebudayaan dan proses sosial. Penelitian ini mengkaji bagaimana konsep diri yang terkait dengan kesadaran lingkungan pada kaum vegetarian dan vegan di Britania Raya. Metode yang dipakai adalah fenomenologi dengan pendekatan kualitatif deskriptif dan teknik pengumpulan data wawancara. Relevansi penelitian ini adalah untuk melihat bagaimana faktor internal dan eksternal memengaruhi konsep diri seorang individu. Hasil penelitian menunjukkan bahwa alasan utama seseorang menjadi vegetarian atau vegan adalah karena ajaran agama atau budaya. Temuan lain dari penelitian ini adalah bahwa terpaan pesan media tidak berdampak besar pada perubahan konsep diri seorang individu. Komunikasi interpersonal dengan orang lain seperti teman justru lebih efektif dalam membentuk konsep diri seseorang.
\end{abstract}

Kata kunci: Konsep diri, komunikasi interpersonal, vegetarian, vegan, kesadaran lingkungan.

\begin{abstract}
Self-concept is a complex awareness within an individual which involves deep thinking process. In making their own selfconcept, an individual is influenced by internal and external factors. Our self-concept about sustaining or exploiting environment is made by culture and social process. This research reviewed how self-concept was related to environmental consciousness in vegetarians and vegans in the United Kingdom. The method used was phenomenology with descriptive qualitative approach and interview as the data gathering technique. The relevance of this research was to see how internal and external factors could influence an individual's self-concept. This research result showed that the main reason why someone became a vegetarian or vegan was because of religious teaching or culture. Another finding in this research was that media message exposure did not have much effect on changing individual's self-concept. Interpersonal communication with others such as friends was found to be more effective in shaping self-concept.
\end{abstract}

Keywords: Self-concept, interpersonal communication, vegetarian, vegan, environmental.

\section{PENDAHULUAN}

Vegetarianisme adalah pola hidup yang sudah ada sejak dahulu kala. Melalui studi literatur, diketahui bahwa Pythagoras, Leonardo da Vinci, dan Leo Tolstoy sudah menganut gaya hidup tanpa daging ini (Spencer, 1995). Selain dianut oleh para filsuf yang hingga kini masih terus dipelajari karya-karyanya, prinsip vegetarianisme juga dipegang oleh penganut sejumlah agama besar di dunia. Dua contoh agama besar yang menerapkan pola makan ini adalah Hindu dan Buddha. Dalam agama Hindu, memakan daging adalah sebuah dosa besar. Karma (balasan) yang akan mereka terima bila memakan daging adalah hidup yang menderita di siklus reinkarnasi berikutnya, atau dimakan oleh hewan yang dibunuh oleh orang itu di kehidupan sekarang (Fox, 1999). Hal ini sedikit berbeda dengan tradisi vegetarian yang ada di agama Buddha. Sejumlah orang Buddha tidak akan menolak daging yang sudah tersaji di meja atau diberi oleh orang lain. Namun, ada juga orang-orang Buddha yang tidak akan memakan daging dalam situasi apapun, bahkan tidak mengonsumsi bawang karena meningkatkan nafsu makan dan madu karena berasal dari hewan (Fox, 1999).

Pola makan tanpa daging sendiri sebenarnya masih terbagi menjadi sejumlah aliran. Dua yang paling populer adalah vegetarian dan vegan. Vegetarian adalah diet yang pada dasarnya menghindari konsumsi berbagai macam produk hewani. Akan tetapi, secara khusus ada kategori lacto ovo vegetarian yang masih mengonsumsi susu, telur, dan berbagai produk olahannya. Lalu lacto vegetarian masih mengonsumsi 
susu dan berbagai produk olahannya, serta ovo vegetarian yang masih mengonsumsi telur dan berbagai produk olahannya (Stanfield \& Hui, 2010). Dalam taraf yang lebih tinggi lagi, ada pola makan vegan yang sudah benar-benar bebas dari produk hewani. Terkadang, kaum vegan bahkan memperluas lingkup komitmen mereka dengan tidak mau memakai produk-produk yang berasal dari kulit atau bulu hewan. Jadi, untuk sebagian orang, vegetarian dan vegan ini telah menjadi sebuah gaya hidup, bukan sekadar pola makan.

Vegetarianisme yang populer di dunia modern ini rupanya berasal dari filosofi yang sudah ada ribuan tahun lalu, yaitu sekitar 500 SM pada era kehidupan Buddha di India dan Pythagoras di Yunani. Mereka percaya bahwa manusia tidak boleh membunuh untuk makan karena adanya konsep reinkarnasi. Jadi, manusia yang bermoral harus selalu menghindari pembunuhan, perselisihan, dan perang (Spencer, 1995). Pandangan berbasis moral ini masih bertahan hingga sekarang. Saat ini, banyak penganut pola makan vegetarian dan vegan yang menyatakan alasan serupa. Salah satu alasan mereka tidak mengonsumsi daging adalah prinsip bahwa pembunuhan makhluk hidup untuk alasan kepuasan lidah semata itu tidak bermoral. Karena itu, vegetarianisme yang berkembang sekarang sebenarnya masih berakar dari pola pikir yang sama ribuan tahun lalu. Sejak dahulu manusia sudah mencapai kesadaran diri bahwa di atas pemenuhan nafsu duniawi, ada prinsip-prinsip yang lebih penting untuk ditaati. Nilai-nilai moral yang kita pegang teguh inilah yang menjadi ciri khas manusia.

Dalam menentukan berbagai hal dalam hidup, manusia dipengaruhi oleh berbagai aspek. Salah satu aspek yang berpengaruh besar adalah orang-orang terdekat dan interaksi kita dengan mereka. Tak hanya berpengaruh dalam proses pengambilan keputusan, konsep diri kita pun terbentuk dari interaksi dengan orang lain di lingkungan sekitar. Seperti dipaparkan oleh West \& Turner (2018), seorang individu membentuk konsep dirinya berdasarkan interaksi dengan orang lain. Konsep diri ini bukanlah sesuatu yang kita miliki sejak lahir, melainkan kita bentuk perlahanlahan melalui hubungan dengan orang lain. Jadi, sebagai makhluk sosial, konsep diri dan keputusankeputusan yang kita ambil selalu tidak lepas dari pengaruh orang-orang di lingkungan sekitar.

Untuk menerangkan self concept atau konsep diri, kita harus memahami makna kata self dengan baik. Menurut Hattie (2014), beberapa deskripsi dari self adalah; 1. Subkek kesadaran yang memiliki proses mental kompleks yang dialami dengan penuh perhatian, dan 2. Individu yang memiliki proses dan fungsi mental dengan sistem yang terorganisir dan progresif. Melihat dua penjelasan ini, dapat disimpulkan bahwa self concept adalah sebuah konsep tentang pribadi yang memiliki proses pemikiran kompleks dan rasa kesadaran tinggi. Orang tidak akan bisa memiliki konsep diri apabila dia tidak memiliki pola pikir yang terorganisir dan kompleks. Jadi setiap orang memiliki konsep diri yang berbeda berdasarkan permenungan dan pemikirannya sepanjang hidup.

Dalam proses pembentukan konsep diri, individu dan kelompok dipengaruhi oleh kebudayaan dan proses sosial. Karena itu, norma sosial memberi batasan untuk tindakan-tindakan individu (West \& Turner, 2018). Dengan kata lain, setiap individu pasti terkena pengaruh norma-norma dan budaya yang berlaku di tempat tinggal atau lingkungan pergaulannya. Jika keluarga atau orang-orang terdekat memercayai nilai tertentu, sedikit atau banyak orang itu akan terpengaruh juga. Meski demikian, perlu diingat bahwa konsep diri muncul dari proses pemikiran yang kompleks dan membutuhkan kesadaran tinggi. Karena itu, orang yang kritis tentu akan lebih selektif dalam menerima nilai-nilai tertentu karena ia akan berusaha mencerna paham itu dengan baik sebelum mempercayainya.

Vegetarianisme yang dilandasi dengan moralitas dapat dijelaskan oleh konsep environmental consciousness (EC). Samdahl dan Robertson (1989) dikutip dari Huang (2014) menjelaskan bahwa EC merupakan kepercayaan yang mengacu pada ide deskriptif seseorang tentang perilaku dan hal tertentu yang mencerminkan evaluasi konsisten, perasaan, dan kecenderungan orang tersebut terhadap satu konsep atau hal. Sedangkan menurut Alsmadi (2007), EC adalah perbuatan yang menunjukkan rasa tanggungjawab yang besar terhadap alam dengan cara mendukung upaya-upaya perlindungan dan pelestarian lingkungan serta aktif mendorong orang lain untuk bertindak serupa. Jadi secara singkat, kesadaran lingkungan atau environmental consciousness adalah komitmen untuk melestarikan alam secara aktif dengan berbagai cara. Dengan kata lain, EC merupakan self-concept para aktivis, pecinta lingkungan, dan semua orang yang aktif melakukan serta mengkampanyekan berbagai kegiatan pelestarian alam.

Pola makan vegetarian sendiri menjadi sebuah tindakan yang sangat mencerminkan EC karena faktanya industri daging merupakan salah satu penyebab utama pemanasan global. Sesuai laporan 
Steinfeld (2006) dikutip dari Hirschler (2008), peternakan adalah satu dari tiga kontributor terbesar masalah lingkungan, baik dalam taraf lokal ataupun global. Efek industri ini sangat besar sehingga harus diselesaikan secepatnya. Dalam laporan yang sama, dijelaskan bahwa ternak menggunakan 30\% dari total seluruh permukaan bumi serta menjadi penyebab utama penebangan hutan, terutama Amazon. Bisnis ini juga salah satu sektor yang paling merusak lingkungan karena memperparah pencemaran air, degenerasi terumbu karang karena kotoran ternak, polusi dari antibiotik dan hormon yang digunakan, dan pencemaran tanah dari pupuk serta pestisida yang dipakai untuk tanaman pakan ternak (Hirschler, 2008).

Di masa disrupsi teknologi ini, semua orang makin mudah mendapatkan informasi. Untuk negara-negara Barat, periode tahun 1990-an adalah masa di mana para jurnalis lingkungan mulai menjadi reporter spesialis yang full time dan canggih karena dibantu oleh internet dan organisasi profesional seperti Society of Environmental Journalist (Senecah, 2004). Di awal tahun 1990-an, seorang jurnalis senior juga menyatakan bahwa jurnalisme lingkungan sudah berkembang, tidak hanya membahas polusi dan makhluk hidup namun juga manajemen tanah, keberlanjutan, perubahan iklim, teknologi baru seperti mobil hybrid, efisiensi energi, spesies invasif, dan sebagainya (Senecah, 2004). Jadi bisa disimpulkan bahwa orangorang yang tinggal di Eropa dan sudah remaja atau dewasa di tahun 2000-an sudah terpapar oleh jurnalisme lingkungan yang baik. Besar kemungkinan mereka telah memahami bahwa gaya hidup vegetarian dan vegan dapat melindungi lingkungan. Bila dahulu jurnalisme lingkungan hanya membahas tentang bencana alam atau sumber daya, sekarang tema-tema yang lebih penting dan relevan seperti pemanasan global sudah sering disinggung. Selain itu, seiring dengan meningkatnya kesadaran publik akan lingkungan, aksi-aksi pelestarian lingkungan seperti mengurangi sampah, membatasi konsumsi energi, dan menggunakan zat-zat tidak berbahaya terus dikampanyekan (Lee, 2013). Secara spesifik penelitian ini dilakukan di Britania Raya karena menurut Environmental Performance Index (EPI), badan internasional yang membuat ranking performa negara secara kuantitatif atas upayanya menanggulangi permasalahan lingkungan dalam berbagai sektor, Britania menduduki posisi keempat (Yale Center for Environmental Law \& Policy, 2020). Penelitian ini menjadi relevan untuk dilakukan pada negara yang telah melakukan upaya-upaya nyata di bidang manajemen daur ulang sampah, pelestarian spesies bina- tang, kontrol emisi zat karbon, dan berbagai tindakan peduli bumi yang lain karena masyarakatnya diasumsikan telah memiliki kesadaran lingkungan yang baik. Jika penelitian ini dilakukan pada negara yang memiliki performa rendah secara indeks EPI, maka sangat besar kemungkinan hasil penelitian tidak dapat menunjukkan proses pembentukan konsep diri kaum vegetarian dan vegan yang memilih gaya hidup ini atas dasar kepedulian pada lingkungan.

Berdasarkan pemaparan di atas, telah dijelaskan bahwa latar belakang orang yang menjadi vegetarian atau vegan untuk alasan moralitas didasari oleh komitmen serta hasil pemikiran konsep diri yang kompleks. Melihat fenomena ini, peneliti tertarik untuk mencari tahu bagaimana konsep self concept dari orang-orang yang menjadi vegetarian tersebut. Ada banyak alasan orang menjadi vegetarian atau vegan; agama, moral, kesehatan, lingkungan, dan sebagainya. Penelitian ini menjawab bagaimana konsep diri para vegetarian dan vegan yang memutuskan untuk tidak makan daging lagi serta melihat bagaimana proses terbentuknya self concept tersebut.

\section{LITERATURE REVIEW}

Penelitian terdahulu yang mengambil sampel vegetarian dan vegan telah dilakukan oleh Daniel L. Rosenfeld (2018). Penelitian tersebut membandingkan bagaimana motivasi dan kebanggaan diri kaum vegetarian dan vegan dengan hasil yang menunjukkan bahwa kaum vegan merasa lebih bangga dan termotivasi dalam menjalankan pola makannya dibandingkan kaum vegetarian. John B. Nezlek dan Catherine A. Forestell (2019) juga meneliti bagaimana pola makan vegetarianisme adalah identitas sosial yang mempengaruhi nilai-nilai, perilaku, dan kehidupan seseorang. Walau begitu, di penelitian ini disebutkan bahwa masih belum diketahui dengan jelas apa alasan-alasan orang memilih gaya hidup vegetarian. Dua penelitian ini menjadi pengantar ke analisis konsep diri kaum vegetarian dan vegan di Britania Raya. Dengan dukungan data bahwa vegetarianisme bukan sekadar perilaku tidak memakan daging, pembentukan konsep diri orang-orang yang memilih gaya hidup ini menjadi menarik untuk diteliti. Dari sudut pandang metode, penggunaan fenomenologi juga pernah dilakukan Sachi Edwards untuk menginvestigasi bagaimana kehidupan kaum vegetarian dan vegan sebagai minoritas.

Dalam teori interaksi simbolik dinyatakan bahwa manusia termotivasi untuk berperilaku berdasarkan makna yang melekat pada orang, benda, atau kejadian 
lain. Makna ini terbentuk dalam bahasa yang digunakan dalam komunikasi interpersonal serta dalam selftalk yang terjadi dalam diri seseorang (West \& Turner, 2018). Jadi, self concept dan self talk ini erat kaitannya dengan keputusan seseorang untuk berperilaku. Dalam kasus yang sedang dibahas saat ini, kedua konsep tadi sangat erat kaitannya dengan keputusan seseorang menjadi vegetarian atau vegan. Pada umumnya semua orang suka memakan daging, karena itu keputusan untuk menjadi vegetarian ataupun vegan tidaklah mudah. Keputusan dan komitmen ini hanya bisa diambil bila seseorang sudah berpikir matang-matang atau berdiskusi dengan dirinya sendiri (seperti konsep self talk) dan memutuskan untuk berkomitmen tidak memakan daging lagi.

Keputusan sulit tadi tidak lepas dari pengaruh media yang pesan-pesannya terus menerpa masyarakat. Orang-orang yang hidup di negara-negara maju seperti Britania Raya jelas sudah sering terpapar oleh gagasan menyelamatkan lingkungan melalui gaya hidup bebas daging. Sesuai dengan teori agenda setting, media diketahui memiliki potensi besar untuk menstruktur isu pada publik, apa yang diterima dan dipersepsi oleh publik bukanlah fenomena yang sesungguhnya terjadi namun sesuatu yang telah dikonstruksi oleh media, mereka bahkan bisa menentukan apa yang harus kita pikirkan (Littlejohn \& Foss, 2011). Ditambah lagi, teori kultivasi menambahkan bahwa televisi bisa membawa cara pandang baru terhadap dunia, teori ini menjelaskan bahwa televisi sudah menjadi bagian yang tidak bisa dipisahkan dari masyarakat kita sehingga pesanpesannya sangat berpengaruh besar pada kita (Littlejohn \& Foss, 2011). Teori-teori menjelaskan bahwa pesan yang diangkat oleh media dapat langsung memberi dampak yang signifikan terhadap audiensnya.

Tak heran, jumlah orang yang mengikuti gaya hidup vegetarian dan vegan di Britania Raya terus meningkat pesat dari tahun ke tahun. Berdasarkan data dari International Vegan Society, pada tahun 2014 hanya $0,25 \%$ penduduk yang menjadi vegan. Angka ini naik hingga 2 kali lipat menjadi 0,46\% di tahun 2016 dan melonjak drastis hingga 1,16\% per tahun 2019 (Vegan Society, 2019). Meski persentasenya memang masih kecil, tren ini menunjukkan bahwa jumlah orang yang mengikuti gaya hidup vegan terus meningkat dalam beberapa tahun terakhir. Kelak, bukan tidak mungkin gaya hidup vegetarian dan vegan akan menjadi mayoritas. Hal ini sesuai dengan pemaparan West \& Turner (2018), struktur sosial bisa diubah oleh interaksi individu dalam masyarakat.
Tiap-tiap individu memiliki keputusan untuk memilih, jika pilihan yang dibuat ini berbeda dari konvensi dan dilakukan terus-menerus, maka pilihan itu bisa menjadi sebuah struktur sosial yang baru.

\section{METODE PENELITIAN}

Penelitian ini menggunakan metode fenomenologi yang bertujuan untuk mendeskripsikan sebuah fenomena dengan akurat sesuai fakta yang ada tanpa mengikuti Batasan-batasan yang dibuat oleh peneliti (Groenewald, 2004). Para pakar fenomenologi focus pada pemahaman fenomena sosial dan psikologis dari perspektif langsung orang yang terlibat (Welman \& Kruger, 1999). Penelitian kualitatif deskriptif ini menggunakan teknik wawancara untuk mengumpulkan data. Pendekatan kualitatif dipilih karena peneliti awalnya melakukan prediksi atas variabel-variabel yang terlibat dalam hubungan bersifat korelatif (Nugrahani, 2014). Selain itu, penelitian dilakukan dalam situasi yang natural tanpa ada intervensi sedikit pun dari peneliti. Tujuan dari penelitian ini adalah memahami obyek penelitian secara mendalam, karena itu pengumpulan data dilakukan dengan wawancara personal (hanya peneliti dengan satu obyek penelitian).

Paradigma yang dipakai adalah pospositivistik dengan tujuan penelitian yang bersifat eksplanatif karena peneliti berusaha untuk memahami karakteristik dan hubungan yang sistemik dalam fenomena berdasarkan fakta (Nugrahani, 2014). Penelitian ini dapat dikategorikan sebagai kajian studi kasus. Fenomena di lapangan dianalisis dengan teori yang didapat dari studi literatur dan kemudian diteliti hubungan korelasinya dengan fenomena riil yang terjadi di lapangan.

Subjek penelitian ini adalah orang-orang yang bekerja di katering penyedia makanan vegetarian serta vegan. Peneliti memilih subjek ini karena pemilik atau penanggungjawab katering yang menyediakan menu vegetarian dan vegan tentu memahami alasan-alasan mengapa orang memesan makanan tanpa daging. Ketimbang mewawancara satu per satu orang yang memesan makanan vegetarian dan vegan, lebih efektif dan efisien untuk mewawancarai para pemilik katering. Hal ini juga merupakan keterbatasan peneliti karena tidak mungkin mencari para pemesan katering makanan vegetarian dan vegan yang tersebar di seluruh area Britania Raya. Tiga orang yang dipilih untuk menjadi subjek penelitian ini berasal dari tiga katering yang tersebar di tiga kota berbeda di seluruh Britania Raya. Pertama ada David Barker, perwakilan 
dari penyedia layanan katering My Chef yang berbasis di Kota Manchester. Setelah itu ada Rajesh Joshi dari Manav Seva yang berbasis di Kota Leicester dan Magdalena Malkinska dari katering Dante's yang berbasis di Kota Belfast.

My Chef merupakan katering yang berada di Manchester, Inggris, dan dipilih karena merupakan katering yang besar dan terpercaya. Mereka memiliki klien lebih dari 850 perusahaan besar dan sudah berdiri sejak tahun 1989. Awalnya mereka hanya merupakan katering yang sangat kecil dan dikelola oleh sepasang suami istri namun berhasil sukses dan akhirnya bisnis ini dikerjakan secara profesional (My Chef, 2020). Manav Seva merupakan katering sekaligus panti jompo yang menyediakan pilihan makanan-makanan vegetarian dan vegan untuk para pelanggan. Organisasi ini dikelola secara nonprofit dan menu makanan yang disediakan kebanyakan merupakan sajian khas India (Manav Seva, 2020). Mereka dipilih untuk mewakili katering sekaligus organisasi nonprofit di Britania Raya. Terakhir ada Dante's, katering yang sudah mulai beroperasi sejak tahun 1990-an awal. Mereka merupakan katering yang terus berkembang sesuai perubahan zaman dan terus-menerus menyajikan berbagai menu vegetarian dan vegan baru demi kebutuhan pasar (Dante's, 2020). Responden ini dipilih karena dalam beberapa tahun terakhir mereka terus membuat inovasi dan menunjukkan komitmennya untuk menyajikan menu vegetarian dan vegan yang berkualitas.

\section{HASIL DAN PEMBAHASAN}

Hasil wawancara menunjukkan bahwa rata-rata orang di Britania Raya menjadi vegetarian atau vegan untuk alasan kesehatan. Dari tiga orang perwakilan katering yang diwawancarai, itulah alasan utama orang-orang tidak memakan daging. Alasan kedua yang paling populer adalah karena agama dan budaya. Biasanya alasan ini berasal dari orang yang beragama Islam, Yahudi, Hindu, Buddha, atau menganut tradisi tertentu. Masing-masing dari mereka sebenarnya memiliki aturan yang berbeda-beda tentang mengonsumsi daging (orang Muslim tidak makan daging babi, orang Hindu dan Buddha vegetarian atau vegan), namun supaya aman, mereka memilih untuk tidak makan daging sama sekali. Alasan lain yang kadang diberikan oleh konsumen adalah mereka memang suka menu tersebut. Terkadang orang-orang ini sebenarnya makan daging secara bebas namun memilih untuk memesan menu vegetarian dan vegan tersebut karena menyukai rasanya.
Menurut Rajesh, sebagian besar orang di Kota Leicester yang memesan makanan vegetarian dan vegan di Manav Seva adalah orang-orang tua yang perlu mengatur pola makannya. Karena itu mereka memilih untuk makan hidangan tanpa daging. Berdasarkan pengakuan para konsumen, kondisi kesehatan mereka menjadi jauh lebih baik setelah tidak makan daging lagi. Sebagian besar konsumen Manav Seva memang merupakan orang yang sudah berumur karena organisasi nonprofit mereka juga memiliki sebuah panti jompo. Jadi dari mulut ke mulut mulai tersebar bahwa gaya hidup vegetarian dapat membuat tubuh lebih sehat dan mencegah datangnya pneyakit-penyakit degeneratif seperti sakit jantung, kolesterol, dan tekanan darah tinggi.

Hal serupa dipaparkan oleh Magdalena, para konsumen katering Dante's di Kota Belfast juga banyak yang peduli dengan kesehatan sehingga memilih untuk tidak makan daging. Banyak orang-orang yang aktif berolahraga, terutama yoga, rutin memesan katering vegetarian di Dante's. Beberapa dari pelanggan mereka bahkan rutin menggelar acara bersama yang seluruh menu makanannya bebas daging. Magdalena bahkan bercerita bahwa makananmakanan vegan mereka sangat lahir sehingga sejumlah konsumen mereka banyak yang memesan lagi menu makanan itu di kemudian hari setelah sudah pernah mencoba. Beberapa dari mereka bahkan mengaku jika makanan vegetarian dan vegan yang dibuat oleh Dante's tidak kalah enak dari makanan yang berasal dari daging sehingga mereka sangat puas. Selain bisa menjaga kesehatan, mereka juga tidak perlu mengorbankan rasa.

David dari My Chef Manchester menambahkan bahwa sebagian besar orang yang memesan menu vegetarian dan vegan adalah karena mereka memiliki alasan religius dan budaya. Dari My Chef, konsumen paling banyak memesan makanan halal dan masakan vegetarian Asia. Sejak mulai beroperasi lebih dari 25 tahun lalu, My Chef sudah memiliki opsi menu makanan vegetarian. Meski tidak bisa menyebutkan kenaikan persentasenya secara spesifik, David menjelaskan bahwa dari tahun ke tahun jumlah pemesan makanan vegetarian terus bertambah di Manchester. Sebagian dari mereka masih belum $100 \%$ vegetarian, terkadang masih memakan ayam atau ikan namun terus berusaha untuk mengurangi asupan daging.

Berdasarkan hasil wawancara, ditemukan fakta bahwa orang-orang di Britania Raya sudah banyak yang memiliki konsep diri tinggi. Mereka peduli dengan kesehatan raganya sehingga tidak ragu untuk meng- 
ambil keputusan menjadi vegetarian dan vegan. Sesuai dengan pemaparan yang telah dijelaskan, konsep diri merupakan keadaan di mana seorang pribadi memiliki pemikiran yang kompleks serta kesadaran tinggi. Orang yang memiliki konsep diri rendah bisa saja hanya mengetahui sebuah fakta secara kognitif namun tidak memikirkannya. Mereka yang memiliki kesadaran diri menengah mungkin memikirkan pola makan vegetarian dan menjalankannya secara parsial. Namun mereka yang benarbenar berkomitmen pada pola makan ini berarti memang sungguh memiliki kesadaran diri yang tinggi. Alasan utamanya adalah, tentu tidak mudah untuk berhenti makan daging karena secara umum semua orang tumbuh besar dengan berbagai macam hidangan olahan daging. Jika seseorang tidak benarbenar berkomitmen, ia tidak akan bisa menjadi seorang vegetarian. Berdasarkan temuan ini terlihat bahwa kaum vegetarian dan vegan di Britania raya memiliki konsep diri yang tinggi.

Akan tetapi, keputusan mereka untuk menjadi vegetarian dan vegan ternyata tidak dilandasi oleh environmental consciousness. Ada 2 kemungkinan yang bisa terjadi yaitu mereka memahami permasalahan lingkungan yang sedang terjadi namun memutuskan untuk tidak ikut mengambil bagian dalam upaya mengurangi jejak karbon, atau mereka tidak menerima pesan media dengan baik sehingga tidak tahu bahwa menjadi vegetarian atau vegan merupakan salah satu cara paling efektif untuk memerangi perubahan iklim. Terlepas dari kedua kemungkinan yang bisa terjadi tersebut, mereka tetap memutuskan untuk berhenti memakan daging supaya bisa menjaga kesehatan. Artinya, secara umum masyarakat lebih peduli dengan apa yang terjadi pada dirinya secara langsung. Memang masalah lingkungan tidak memiliki dampak yang langsung dan signifikan pada tiap individu. Bisa saja polusi menyebabkan kualitas udara memburuk dan membawa penyakit pada manusia. Akan tetapi efek ini tidak bisa dirasakan secara langsung dan tidak langsung bisa dikaitkan dengan perilaku seorang individu. Karena itulah lebih sulit untuk mengubah perilaku seseorang demi kebaikan bersama karena tidak ada efek jera yang langsung dirasakan. Berbeda dengan menjaga kesehatan badan masing-masing. Bila pola makan tidak dijaga, maka seseorang bisa langsung terkena penyakit yang menyebabkan keterbatasan dalam beraktivitas atau bahkan kematian.

Dari sisi pembentukan konsep diri, disebutkan bahwa seorang individu akan dipengaruhi oleh kebudayaan dan proses sosial. Tidak mengherankan kalau di negara seperti Britania Raya orang-orang lebih mudah menjalani masa transisi untuk menjadi seorang vegetarian atau vegan karena kebudayaan dan lingkungan sosial yang mendukung. Di negara-negara Eropa menjadi vegetarian bukanlah hal yang aneh. Sudah banyak orang yang tidak makan daging untuk berbagai macam alasan seperti kesehatan, moral, dan untuk lingkungan. Jadi, lebih mudah untuk seorang individu menjadi vegetarian. Secara budaya dan pergaulan, pola makan ini tidak dianggap aneh. Ketika kita pergi ke rumah makan atau supermarket, berbagai pilihan makanan vegetarian dan vegan juga murah ditemui. Bahkan katering-katering di Britania Raya juga sudah banyak yang menyediakan pilihan menu makanan vegetarian dan vegan seperti Manav Seva, My Chef, dan Dante's. Tiga katering ini sudah beroperasi selama bertahun-tahun dan memiliki bukti data bahwa setiap tahunnya jumlah pemesan makanan vegetarian selalu bertambah. Inilah salah satu alasan mengapa transisi menuju pola makan yang bebas daging di Britania Raya jauh lebih mudah bila dibandingkan negara-negara yang masih belum familiar dengan pola makan seperti ini, contohnya Indonesia. Di negara kita saat ini sudah mulai banyak dijual bahan-bahan makanan yang bebas bahan dasar hewani seperti keju, susu, dan telur. Makanan semacam ini sangat populer di daerah yang ramai dikunjungi turis mancanegara seperti Bali. Ini menunjukkan bahwa bila ada kebutuhan dari konsumen dan ada lingkungan sosial yang mendukung, perubahan menuju pola makan vegetarian akan menjadi lebih mudah. Orang yang memiliki konsep diri vegetarian akan sangat terbantu dalam memegang prinsipnya.

Sebelumnya telah disebutkan pula bahwa manusia termotivasi untuk berperilaku berdasarkan makna yang terbentuk dalam komunikasi interpersonal dan intrapersonal. Selain mendapatkan dukungan dari orang-orang di sekitar, seorang vegetarian tentu juga sudah mengalami self talk dalam dirinya sendiri sebelum memutuskan untuk tidak makan daging lagi. Rajesh dari Manav Seva menceritakan bahwa sebagian pelanggannya yang memesan makanan vegetarian tertarik untuk mencoba pola makan ini setelah diceritai oleh temannya. Awalnya konsumen katering vegan Manav Seva tidaklah banyak, namun para konsumen ini kemudian bercerita pada temantemannya bahwa setelah rutin mengonsumsi makanan yang bebas daging, tubuh mereka terasa lebih segar dan sehat. Setelah itu makin banyaklah orang yang tertarik untuk menjadi vegetarian karena terpengaruh dari komunikasi antarpribadi yang dilakukan oleh para konsumen awal. Hal ini mendukung teori self-concept yang menyatakan bahwa seorang 
manusia biasanya termotivasi untuk berperilaku berdasarkan makna yang terbentuk dalam komunikasi intrapersonal dan interpersonal. Secara intrapersonal tentunya seseorang sudah berdialog dengan dirinya sendiri sebelum memutuskan untuk berhenti makan daging. Sedangkan secara interpersonal keputusan kita ternyata juga sangat dipengaruhi oleh komunikasi yang kita lakukan dengan orang-orang di sekitar.

Melihat banyaknya konsumen katering di Britania Raya yang menjadi vegetarian untuk alasan kesehatan, bisa disimpulkan bahwa mereka takut akan makin banyaknya penyakit-penyakit gaya hidup di dunia modern ini. Dari tahun ke tahun makin banyak orang yang terkena penyakit seperti stroke, serangan jantung, kolesterol, atau diabetes di usia yang relatif muda. Karena itu, tak mengherankan bahwa banyak masyarakat yang memiliki konsep diri ingin menjadi vegetarian demi kesehatan. Mereka adalah orangorang yang sudah memikirkan dan mempertimbangkan dengan baik setiap konsekuensi dari pilihan yang diambil. Secara umum terdapat dua kategori orang yang menjadi vegetarian atau vegan demi menjaga kesehatan. Pertama yaitu mereka yang sejak muda sudah mulai berkorban tidak mengikuti kenikmatan makanan hewani agar kelak di usia tua ancaman untuk terkena berbagai macam penyakit kronis sudah berkurang drastis. Kedua yaitu orang-orang yang sudah terlanjur sakit baru kemudian menjadi vegetarian, berarti mereka sudah merasakan sendiri tidak enaknya sakit dan baru memutuskan mulai saat ini tidak akan memilih gaya hidup yang tidak sehat lagi. Kesadaran orang tipe kedua ini lebih terlambat dibandingkan mereka yang sudah mau menjadi vegetarian sebelum terkena penyakit apapun.

Hasil penelitian ini juga menunjukkan bahwa tidak terlihat dampak langsung dari paparan pesan-pesan media terhadap environmental consciousness para pelanggan katering vegetarian dan vegan di Britania Raya. Meskipun jurnalisme lingkungan telah berkembang dengan pesat dan terus membahas dampak lingkungan dari konsumsi daging, mayoritas penganut gaya hidup vegetarian dan vegan di Britania Raya rupanya tidak melakukan perubahan ini demi lingkungan. Temuan ini menarik karena jika kita menggunakan pendekatan teori agenda setting dan kultivasi, dijelaskan bahwa pesan media dapat langsung membawa efek pada masyarakat. Walau media telah banyak menyampaikan pesan-pesan konservasi lingkungan dan pentingnya gaya hidup bebas daging, kenyataannya mayoritas orang tidak menjadi vegetarian karena ingin menyelamatkan lingkungan. Salah satu penyebab dari hal ini adalah karena makin hari orang makin selektif dalam mengonsumsi media. Dahulu kita yakin bahwa media massa memiliki kekuatan yang begitu besar untuk memengaruhi masyarakat. Dalam teori kultivasi bahkan dijelaskan bahwa dengan menonton televisi kita akan makin percaya dengan apa yang ada di televisi, bukan apa yang riil kita lihat di kehidupan nyata. Namun faktanya orang bisa dengan mudah mengubah channel televisi atau bahkan mengabaikan apa yang sedang ia tonton. Bisa saja audience hanya menyalakan televisi lalu mengabaikannya karena sibuk melakukan aktivitas lain di saat bersamaan. Ada begitu banyak noise yang bisa mengganggu audiens dalam mengonsumsi pesan-pesan dari televisi.

Keadaan ini diperparah dengan kecenderungan para jurnalis sebelum tahun 2000-an yang sering membuat berita dengan judul bombastis. Judul-judul yang menakutkan ternyata terbukti tidak efektif dalam menarik minat pembaca. Sebagian besar orang yang membaca berita dengan judul menarkutkan justru bersikap skeptis dan menjadi tidak percaya. Hal ini justru menimbulkan efek kebalikan yang sangat tidak diinginkan oleh para ilmuwan di seluruh dunia. Alihalih mengedukasi dan mengajarkan masyarakat untuk lebih menghargai dan melindungi lingkungan, media massa justru menggiring audiens untuk tidak percaya pada isu yang sangat penting ini. Masyarakat yang sudah teredukasi dengan baik, contohnya para penduduk Britania Raya, bisa saja malah merasa media hanya berusaha menaikkan rating atau menarik minat audiens dengan judul yang provokatif tadi, bukan tulus memberikan informasi yang jujur tentang kondisi lingkungan saat ini.

\section{KESIMPULAN}

Analisis menunjukkan bahwa konsep diri kaum vegetarian dan vegan di Britania Raya tinggi. Akan tetapi alih-alih didasari pada environmental consciousness, konsep diri ini berlandaskan oleh penghargaan pada tubuh dan kesehatan masyarakat. Ada yang menjadi vegetarian dan vegan karena sudah sakit, dan ada juga yang sudah melakukan tindakan preventif menjadi vegetarian demi menjaga kesehatan. Mereka yang memilih tidak memakan daging walau tubuhnya dalam kondisi sehat ini memiliki konsep diri yang lebih tinggi dibandingkan mereka yang menjadi vegetarian dan vegan setelah sakit.

Temuan kedua adalah meski paparan media memiliki pengaruh besar terhadap audiens, penelitian ini menunjukkan bahwa orang-orang tidak serta-merta terpengaruh oleh pesan media. Walau media terus menyatakan bahwa pola hidup vegetarian dan vegan merupakan perilaku yang menceriminkan kepedulian pada lingkungan, ternyata pesan ini tidak masuk 
hingga ke tahap perilaku audiens. Hal ini mengindikasikan dua hal, sampel yang dianalisis tidak cukup menerima pesan dari media massa dengan efektif, atau mereka hanya menerima saja tanpa terpengaruh hingga taraf perubahan perilaku.

Sesuai dengan keterbatasan peneliti dalam pencarian informan, rekomendasi untuk penelitian selanjutnya adalah mengambil sampel yang lebih besar di Britania Raya. Penelitian juga bisa dilakukan dengan metode kuantitatif atau mixed method untuk mendapatkan generalisasi apakah memang konsep diri kaum vegetarian dan vegan di Britania Raya telah tinggi secara merata di seluruh negeri.

\section{DAFTAR PUSTAKA}

Alsmadi, A. (2007). Green Marketing and the Concern over the Environment: Measuring Environmental Consciousness of Jordanian Consumers. Journal of Promotion Management, 13(34), pp. 339-361.

Dante's. (2020). Home Page. Retrieved from https:// www.dantes.co.uk/

Hattie, J. (2014). Self-Concept. New York: Psychology Press.

Hirschler, C., (2008). An Examination of Vegan's Belief and Experiences Using Critical Theory and Autoethnography. Doctor of Philosophy. Cleveland State University.

Huang, H., Lin, T., Lai, M., and Lin T. (2014). Envitonmental Consciousness and Green Customer Behaviour: An Examination of Motivation Crowding Effect. Elsevier, 40, pp. 139-149.
Fox, M. A. (1999). Deep Vegetarianism. Philadelphia: Temple University Press.

Groenewald, T. (2004). A Phenomenological Research Design Illustrated. International Journal of Qualitative Methods.

Littlejohn, S. W. \& Foss, K. A. (2011). Theories of Human Communication: Tenth Edition. USA: Waveland Press.

Manav Sva. (2020). Home Page. Retrieved from http://manavseva.co.uk/

MyChef. (020). History. Retrieved from https://www. mychef.com/history

Nugrahani F. (2014). Metode Penelitian Kualitatif. Surakarta: akra Books

Senecah, Susan L. (2004). The Environmental Communication Yearbook. New Jersey: Lawrence Erlbaum Associates.

Stanfield, P. S. \& Hui, Y. H. (2010). Nutrition and Diet Therapy: Self-Instructional Approaches. USA: Jones and Bartlett Publishers.

Spencer, C. (1995). The Heretic's Feast: A History of Vegetarianism. Hanover: University Press of New England.

Vegan Society (2019). The Vegan Society Survey. Retrieved from: https://www.vegansociety.com/ news/media/statistics

West, R. \& Turner, L. H. (2014). Introducing Communication Theory: Analysis and Application. New York: McGraw Hill Education.

Yale Center for Environmental Law \& Policy. (2020). Environmental Performance Index. https://epi.yale.edu/epi-results/2020/component/ epi. 